\title{
ОСОБЕННОСТИ ПОДГОТОВКИ И МОНИТОРИНГ ПОДЗЕМНЫХ ВОД В ГОРОДЕ БИЙСКЕ
}

\section{Ольга Алексеевна Сахнова}

Сибирский государственный университет геосистем и технологий, 630108, Россия, г. Новосибирск, ул. Плахотного, 10, обучающийся, тел. (962)790-45-79, e-mail: sahnova.o@mail.ru

В статье обоснована необходимость ведения мониторинга качества подземных вод, используемых для питьевого водоснабжения. Приведена обеспеченность г. Бийск подземными водами. Описаны этапы добычи и подготовки воды. Рассмотрены установленные санитарнозащитные зоны. Перечислены основные цели мониторинга качества подземных вод. Предложено расширить использование геоинформационнных и компьютерных технологий в проведение мониторинга качества подземных вод.

Ключевые слова: подземные воды, водозабор, очистка воды, санитарно-защитные зоны, мониторинг подземных вод, водоотбор, качество питьевой воды

\section{FEATURES OF PREPARATION OF WATER AND MONITORING UNDERGROUND WATER IN THE CITY OF BIYSK}

\section{Olga A. Sakhnova}

Siberian State University of Geosystems and Technologies, 10, Plakhotnogo St., Novosibirsk, 630108, Russia, Student, phone: (962)790-45-79, e-mail: sahnova.o@mail.ru

The article substantiates the need to monitor the quality of underground water used for drinking water supply. The provision of Biysk with underground water is given. The stages of water extraction and treatment are described. The established sanitary protection zones are considered. The main goals of monitoring the quality of underground water are listed. It is proposed to expand the use of geoinformation and computer technologies in monitoring the quality of groundwater.

Keywords: underground water, water intake, water treatment, sanitary protection zones, underground water monitoring, water sampling, drinking water quality

Актуальность данной темы определяется тем, что люди ежедневно используют воду в различных целях, но не химически чистую - дистиллированную, а природную воду, насыщенную разнообразными растворенными веществами. Поэтому необходимо знать особенности подготовки и мониторинга качества воды [2].

Цель данного исследования заключается в рассмотрении особенностей подготовки хозяйственно-питьевой воды при добыче ее из подземных источников и мониторинге ее качества на примере г. Бийска. 
Артезианские воды - это подземные воды, заключённые между водоупорными слоями и находящиеся под гидравлическим давлением. Эти воды перекрыты водонепроницаемыми породами, они защищены от поступления загрязнённых стоков и поэтому обладают высокими санитарными качествами.

Город Бийск полностью снабжается из подземных водозаборов. Используются 48 скважин на трех водозаборах. Водозабор №1 - около 90 тыс. м3/сутки, этими водами пользуется 90\% населения; водозабор №2 - 10 тыс. м3/сутки; водозабор №3 - 5 тыс. м3/сутки.

Добыча воды в г. Бийске происходит следующим образом: для приема подземных вод применяются скважины, которые устраиваются путем бурения в земле вертикальных цилиндрических каналов. На каждой скважине установлен насос определенного вида, с помощью которого вода поднимается по двум трубопроводам и отправляется на очистку [9].

Основная цель очистки воды - защита потребителя от патогенных организмов и примесей, которые могут быть опасны для здоровья человека или иметь неприятные свойства (цвет, запах, вкус и т. д.). Методы очистки выбираются с учетом качества и характера источника водоснабжения [7].

Использование подземных источников вод в качестве источника питьевого водоснабжения имеет определенные преимущества, такие как: защита от загрязненных стоков, постоянство качества, высокая безопасность в эпидемиологическом отношении [12].

Очистка воды проводится в три этапа. На первом этапе вода поступает на станцию обезжелезивания, где происходит окисление растворенного железа с помощью аэрации и фильтрация воды от взвешенных частиц, т.к. подземные источники отличаются большей жесткостью воды. После совершается биологическая очистка от бактерий, вирусов и других микроорганизмов, с целью доведения качества воды по микробиологическим показателям до норм СанПиН 2.1.4.1074-01 [8], для этого применяется хлорная вода, полученная при смешении хлор-газа и очищенной воды при помощи оборудования, установленного в хлораторной станции.

На территории водозабора установлены зоны санитарной охраны. Основная цель создания и обеспечения специального режима в зонах сани-тарной охраны заключается в санитарной охране источников питьевого водо-снабжения, водопроводных сооружений и территории от загрязнения [10].

Рассматривая Водозабор №1 установлена гидравлическая связь между эксплуатируемыми водоносными горизонтами и поверхностными водами р.Бия. В связи с этим, эксплуатируемые водоносные горизонты считаются недостаточно защищенными от поверхностного загрязнения. Следовательно, граница $3 \mathrm{CO}$ должна составлять 50 метров вокруг каждой скважины.

На рисунке показана схема расположения границ зон санитарной охраны первого пояса на Водозаборе №1. 


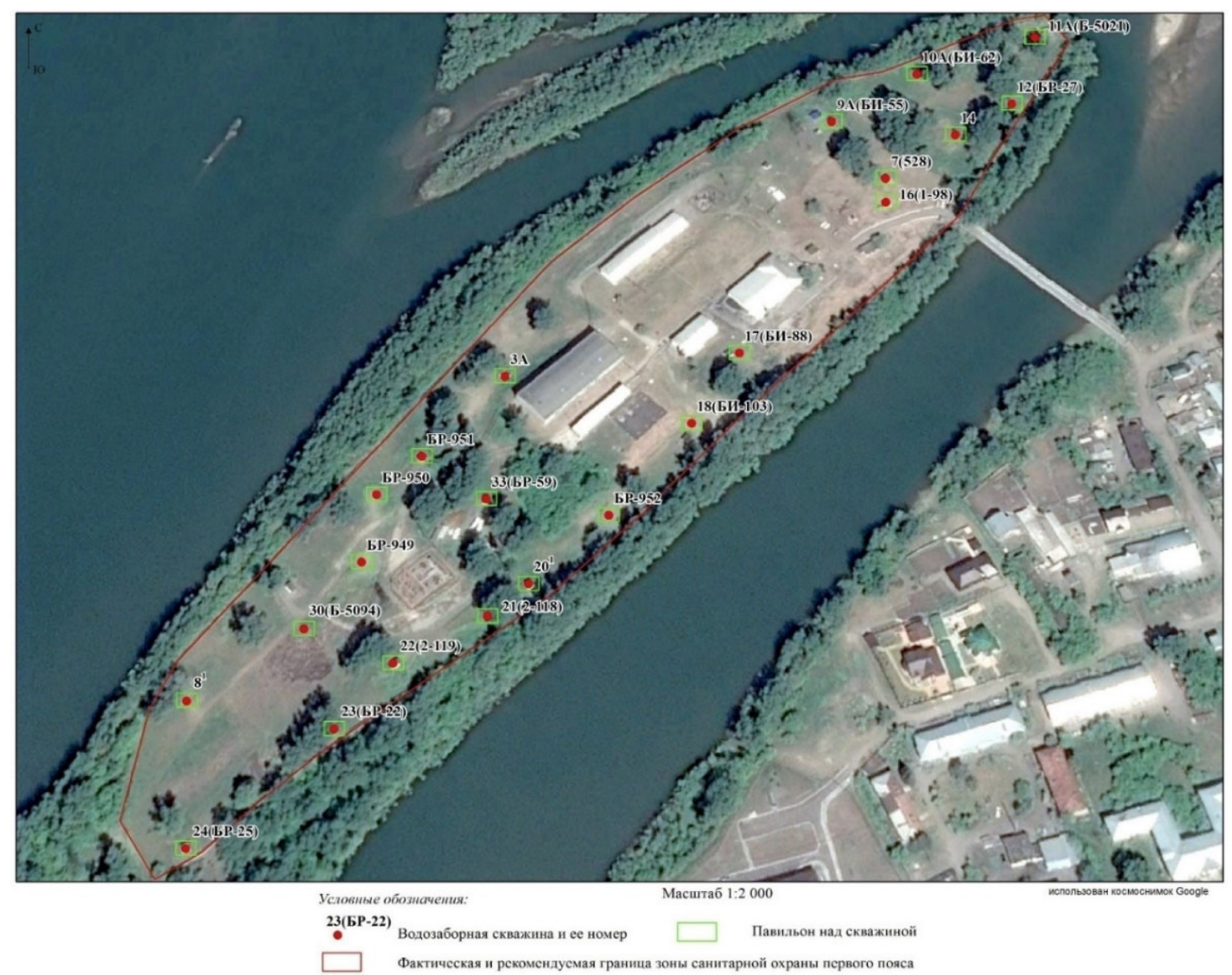

Схема расположения ЗСО первого пояса Водозабора №1, о. Нижний

Для оценки соответствия воды нормам проводится мониторинг месторождений и участков водозаборов питьевых подземных вод, а именно:

- регулярные наблюдения за поземными водами, а также за отдельными компонентами окружающей природной (в том числе геологической) среды в границах влияния эксплуатации водозаборных сооружений;

- регистрация наблюдаемых показателей и обработка полученной информации;

- оценка пространственно-временных изменений состояния подземных вод и связанных с ним компонентов окружающей природной среды на основе данных, полученных в процессе мониторинга;

- прогнозирование изменения состояния подземных водных объектов под влиянием водоотбора и других антропогенных и природных факторов, а также предупреждение о вероятных изменениях состояния подземных вод и необходимой коррекции режима эксплуатации [5].

В общем случае мониторинг подземных вод охватывает как собственно месторождение, так и зону существенного влияния его эксплуатации [4].

Целью мониторинга водозабора питьевых подземных вод является:

- информационное обеспечение процессов управления эксплуатацией подземных вод; 
- охрана подземных вод от загрязнения и истощения;

- предотвращение негативных влияний водоотбора на окружающую среду;

- контроль за соблюдением требований, установленных при предоставлении недр для добычи подземных вод [1];

- разработка рекомендаций про рационализации эксплуатации подземных вод и предотвращению или ослаблению негативных последствий отбора подземных вод [11].

Мониторинг качества вод, отбираемых из скважин, и разработка новых методов их очистки ведутся постоянно [6]. Имеется необходимость более широкого использования геоинформационных и компьютерных технологий. При использовании геионформационных систем появляется возможность создания пространственно-информационнных моделей и получение объективной, точной и актуальной информации [3].

\section{БИБЛИОГРАФИЧЕСКИЙ СПИСОК}

1. "Водный кодекс Российской Федерации" от 03.06.2006 N 74-Ф3 (ред. от 02.08.2019) [Электронный pecypc] / - Электрон. текстовые дан. - Режим доступа: http://www.consultant.ru/document/cons_doc_LAW_60683/.

2. Губонина, 3. И. Промышленная экология. Проблемы питьевой воды [Текст]: учеб. пособ. / З. И. Губонина, С. Н. Владимиров. - М.: МГОУ, 2010. - 100 с.

3. Другов, Ю. С. Мониторинг органических загрязнений природной среды: 500 методик [Текст]: практическое руководство / Ю. С. Другов, А. А. Родин. - 2-изд., доп. и пер. - М: БИНОМ. Лаборатория знаний, 2013. - 893 с.

4. Кирюхин В.А. Современные проблемы регионального мониторинга подземных вод [Электронный ресурс] / В.А. Кирюхин, Л.П. Норова — Электрон. журн. - Режим доступа: https://cyberleninka.ru/article/v/sovremennye-problemy-regionalnogo-monitoringa-podzemnyhvod.

5. Методические рекомендации по организации и ведению мониторинга подземных вод на мелких групповых водозаборах и одиночных эксплуатационных скважинах [Электронный ресурс] \% - Электрон. текстовые дан. - Режим доступа: http://docs.cntd.ru/document/1200069906.

6. Озерский, А.Ю. Состояние и проблемы организации и методики геоэкологического мониторинга подземных вод [Электронный ресурс] / А.Ю. Озерский. - Электрон. журн. Режим доступа: https://cyberleninka.ru/article/v/sostoyanie-i-problemy-organizatsii-i-metodikigeoekologicheskogo-monitoringa-podzemnyh-vod.

7. Рябчиков, Б. Е. Современные методы подготовки воды для промышленного и бытового использования [Текст] / Б. Е. Рябчиков. - М.: ДеЛи принт, 2004. - 328 с.

8. СанПиН 2.1.4.1074-01 Питьевая вода. Гигиенические требования к качеству воды централизованных систем питьевого водоснабжения. Контроль качества. Гигиенические требования к обеспечению безопасности систем горячего водоснабжения [Электронный ресурс] / - Электрон. текстовые дан. - Режим доступа: http://docs.cntd.ru/document/901798042.

9. Технологический регламент Водозабора № 1 [Текст] / Б: МУП г. Бийска «Во-доканал», 2017 г. -155 c. 
10. Фролова, И. В. Охрана поверхностных и подземных вод [Электронный ресурс] / И. В. Фролова, В. А. Картавцев. - Электрон. текстовые дан. - Режим до-ступа: https://cyberleninka.ru/article/n/ohrana-poverhnostnyh-i-podzemnyh-vod/viewer, свободный.

11. Цхаи, А.А. Мониторинг качества системы поверхностных и подземных вод речного бассейна субъекта РФ: модельный подход и информационные средства [Электронный ресурс] / А.А. Цхаи, Н.Ю. Ким, К.Б. Кошелев, и др. - Электрон. журн. - Режим доступа: https://cyberleninka.ru/article/v/monitoring-kachestva-sistemy-poverhnostnyh-i-podzemnyh-vodrechnogo-basseyna-subekta-rf-modelnyy-podhod-i-informatsionnye-sredstva.

12. Чебокчинова, В.А. Источники загрязнения подземных вод // Научное сообщество студентов XXI столетия. Естественные науки: сб. ст. по мат. LXIV меж-дунар. студ. науч.практ. конф. № 5(63) [Электронный ресурс] / - Электрон. текстовые дан. — Режим доступа: https://sibac.info/archive/nature/5(63).pdf, свободный.

(C) O. А. Сахнова, 2021 